\title{
Mid-Holocene Underwater Jomon Sites along the West Coast of Kyushu, Japan, Hydro-isostasy and Asthenospheric Viscosity
}

\author{
Masao Nakada*1, Jun'ichi Okuno*1, Yusuke Yokoyama*2, Shinji Nagaoka*3, \\ Shinji Takano*4 and Yasuo Maeda*5
}

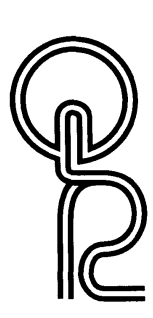

Mid-Holocene underwater Jomon sites typically observed along the west coast of Kyushu, Japan, are reasonably explained by the hydro-isostatic adjustment due to the last deglaciation. The distribution of these underwater Jomon sites is very sensitive to the rheological structure above $250 \mathrm{~km}$ depth, and comparisons between observations and predictions of sea-level variations indicate a lithospheric thickness of $30-50 \mathrm{~km}$ and an effective asthenospheric viscosity $(\sim 200 \mathrm{~km}$ thickness $)$ of $(8-20) \times 10^{19} \mathrm{~Pa}$ s. The viscosity contrast between the asthenosphere and the underlying upper mantle is less than 10 , and a well defined low-viscosity asthenosphere may not exist even in the island arc regions such as the Japanese Islands. Thus regional postglacial sea-levels are spatio-temporally variable and dependent on crustal tilting caused by hydro-isostatic adjustment, and they might have constrained the development of prehistoric human settlements and the way of lives.

Key Words: Underwater Jomon sites, Holocene sea-level changes, hydroisostasy, asthenospheric viscosity

\section{Introduction}

Submerged archeological sites during the Jomon period of the mid-Holocene (underwater Jomon sites with the ages of $6,000-5,000$ years) have been typically observed along the west coast of Kyushu, Japan. Early settlements of Jomon age are shown in Fig. 1, although there are many underwater Jomon sites in this region (Chinzei Town Board of Education, 1989; Nagaoka, 1993 ; Nagasaki Prefectural Board of Education, 1996, 1997). Except for the Takashima site these Jomon sites appear above sea- level at low tide and submerge again at high tide, indicating $1-2 \mathrm{~m}$ subsidence during the past 5-6 kyr (thousand years). The Takashima site is observed at about $-25 \mathrm{~m}$ depth, and the ${ }^{14} \mathrm{C}$ ages for intertidal shells are $8,410 \pm 105$ and $8,630 \pm 105$ years $B P$ (before present) (Nagaoka, 1993). The submerged Takashima site is reasonably explained by the sea-level rise during the late glacial phase (Nakada et al., 1994). What is, however, the cause of the subsidence of these mid-Holocene Jomon sites in the postglacial phase ? This subsidence may be attributed to the postglacial isostatic adjustment due to

Received October 10, 1997. Accepted March 14, 1998.

*1 Department of Earth and Planetary Sciences, Faculty of Science, Kyushu University. 6-10-1 Hakozaki, Higashi-ku, Fukuoka, 812-8581.

*2 Research School of Earth Sciences, Australian National University. Canberra, ACT0200, Australia.

*3 Department of Geography, Faculty of Education, Nagasaki University. 1-14 Bunkyo-cho, Nagasaki, 852-813.

*4 Nagasaki Prefectural Board of Education, Nagasaki Prefecture. 2-13 Edo-machi, Nagasaki, 850-8570.

*5 National Institute of Geological Science, College of Science, University of the Philippines. Diliman, Quezon City, 1101, Philippines. 


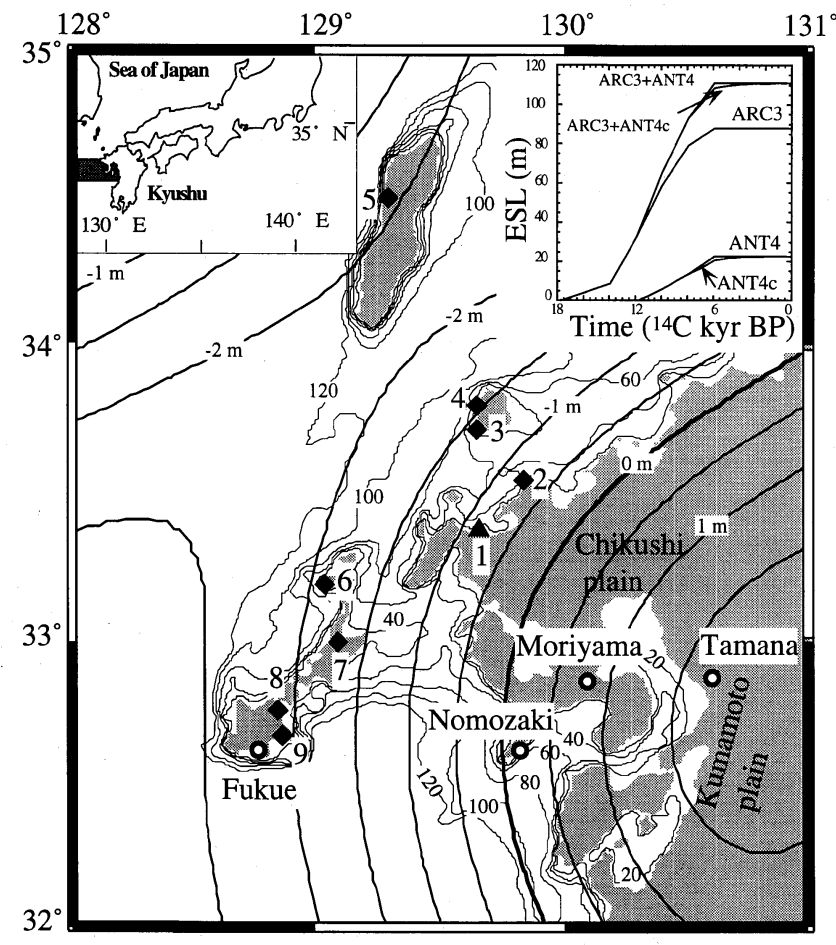

Fig. 1 Location map of underwater Jomon sites recognized as established settlements 1. Takashima site, 2. Akamatsu site, 3. Nakiri site, 4. Matsuzaki site, 5. Meotoishi site, 6. Yabitsu site, 7. Nishinomata site, 8. Dousaki site, 9. Ego site

Predicted contours of Holocene sea-levels at $6{ }^{14} \mathrm{C}$ kyr BP are shown for the ice model ARC3 + ANT4c. The parameters for the earth model used for these predictions are $: \mathrm{H}_{1}$ (lithospheric thickness) $=30 \mathrm{~km}$, $\mathrm{H}_{\mathrm{a}}$ (asthenospheric thickness) $=200 \mathrm{~km}, \eta_{\mathrm{a}}$ (asthenospheric viscosity) $=10^{20} \mathrm{~Pa} \mathrm{~s}, \eta_{\mathrm{um}}$ (underlying upper mantle viscosity) $=2 \times 10^{20} \mathrm{~Pa}$ s and $\eta_{\mathrm{lm}}$ (lower mantle viscosity) $=10^{22} \mathrm{~Pa} \mathrm{~s}$.

the last deglaciation, which is very sensitive to the rheological structure of the Earth (Nakada et al., 1994). It may therefore be possible to use these Jomon sites to constrain the geophysical evolution of the Kyushu area.

Observations of Holocene sea-level variations for this area are required in order to quantitatively investigate the cause of submerged mid-Holocene Jomon sites. Coastal terraces of last-interglacial maximum age $(\sim 125 \mathrm{kyr}$ ago $)$ with an altitude higher than 10 $\mathrm{m}$ have not been reported from the west coast of Kyushu (Ota and Omura, 1991). This region is also seismically inactive (National Astronomical Observatory, Japan, 1992), and there is little active fault in this area (The Research
Group for Active Tectonics in Kyushu, 1989). This region seems to have been tectonically inactive during at least the past $125 \mathrm{kyr}$. In addition to this, there are many peninsulas and islands for which observations are available to constrain crustal tilting. Yokoyama et al. (1996) have extensively surveyed mid- to lateHolocene sea-level variations at sites from Fukue to Tamana along the latitude of about $33^{\circ} \mathrm{N}$ (see Fig. 1). They obtained systematic boring samples at these sites, and analyzed the diatom assemblages, pyrite-sulfur contents of sediment samples and ${ }^{14} \mathrm{C}$ datings for intertidal shells. The observed relative sea-levels by Yokoyama et al. (1996) are shown in Figure 2. Observations at Moriyama show a sea-level 
highstand of $1 \mathrm{~m}$ at about $5.5{ }^{14} \mathrm{C} \mathrm{kyr} \mathrm{BP}$ followed by a gradual decrease to the present sea-level. Relative sea-levels at about $5{ }^{14} \mathrm{C} \mathrm{kyr}$ $\mathrm{BP}$ are, however, $-2 \mathrm{~m}$ at Fukue and $2 \mathrm{~m}$ at Tamana, indicating during the past $5 \mathrm{kyr}$ there has been $3-4 \mathrm{~m}$ of crustal tilting over a distance of $175 \mathrm{~km}$. The relative sea-level at Fukue may therefore be consistent with the submerged Jomon sites. Is it possible to quantitatively explain the observed crustal tilting by hydroisostatic adjustment?

Nakada et al. (1994) have qualitatively shown that these sites may be explained by the hydro-isostatic adjustment due to the last deglaciation. In this paper, we report that these sites are, in fact, explained by this mechanism reasonably.

\section{Geophysical modelling}

The postglacial sea-level variations at sites away from the former areas of glaciation (farfield) are mainly attributed to the Earth's viscoelastic deformation produced by meltwater loading, and are very sensitive to the lithospheric thickness and asthenospheric viscosity and thickness (Nakada and Lambeck, 1987, 1989; Mitrovica and Peltier, 1991; Johnston, 1993). A precise evaluation of short wavelength crustal responses, tightly related to ocean geometry, is very important for modelling sea-level varia-

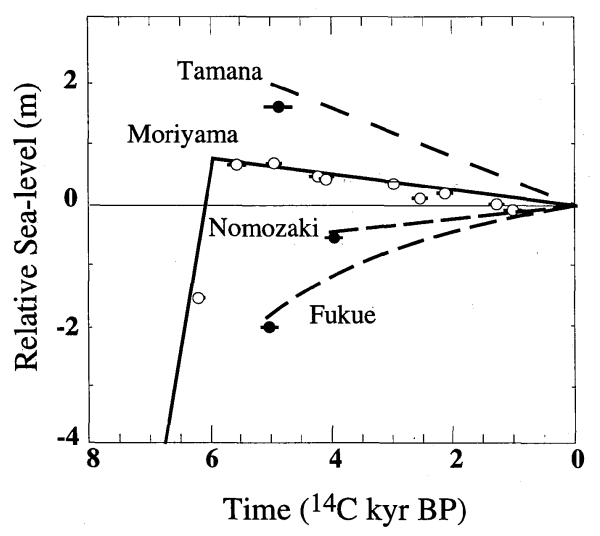

Fig. 2 Sea-level observations by Yokoyama et al. (1996) for the sites illustrated in Fig. 1 tions for areas with a relatively thin lithosphere such as the Japanese Islands (Nakada and Lambeck, 1987, 1989). Since extensive shallow continental shelves occur along the west coast of Kyushu, we should therefore adopt a realistic time-dependent ocean function defining the geometry of the ocean basin in order to accurately evaluate sea-level variations throughout this area. In this study we have used a 6 step ocean function with past shorelines taken at the $100,80,60,40,20$ and $0 \mathrm{~m}$ depth contours. The time corresponding to each depth is approximately estimated by the eustatic sea-level (ESL) of the ice model ARC3+ANT4 (Nakada and Lambeck, 1988, 1989) (see the inset of Fig. 1). This approximation works well in the farfield sea-level calculation because the sea-level variations in the far-field are close to ESL (Johnston, 1993). The predictions obtained with a more detailed ocean function are exactly the same as the results achieved using the 6-step ocean function.

The age differences between ${ }^{14} \mathrm{C}$ and $\mathrm{U} / \mathrm{Th}$ ages are also important for evaluating sea-level variations at sites with a rheologically weak structure. From the work on coral cores (Bard et al., 1990; Eisenhauer et al., 1993), this dif-

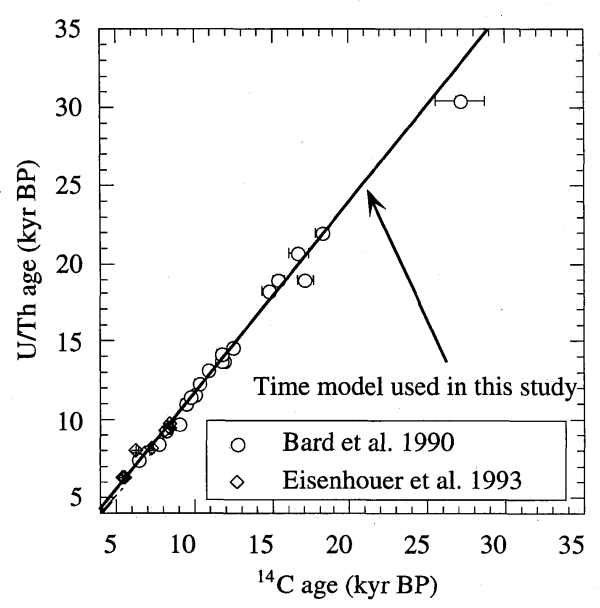

Fig. 3 The age data for ${ }^{14} \mathrm{C}$ and $\mathrm{U} / \mathrm{Th}$ datings obtained by Bard et al. (1990) and Eisenhauer et al. (1993), and the time model used in this study 
ference at about $20 \mathrm{kyr} \mathrm{BP}$ is $3 \mathrm{kyr}$ (Fig. 3). Relaxation time for surface deformation with a wavelength of $400 \mathrm{~km}$, corresponding to a representative wavelength for the area discussed here, is about $3 \mathrm{kyr}$ for an earth model with upper mantle viscosity of $(1-10) \times 10^{20} \mathrm{~Pa} \mathrm{~s}$, comparable to the age difference for both methods. We evaluated the sea-level variations using calendar age, and converted these predictions to ${ }^{14} \mathrm{C}$ ages, because most observations have been presented as ${ }^{14} \mathrm{C}$ ages. An approximate linear relationship between ${ }^{14} \mathrm{C}$ and $\mathrm{U} / \mathrm{Th}$ ages for coral core samples (Bard et al., 1990; Eisenhauer et al., 1993) was adopted for this calibration.

A spatially non-uniform water load is required in evaluating sea-level predictions accurately (Mitrovica and Peltier, 1991 ; Johnston, 1993). In this study, we use an iterative pseudospectral scheme formulated by Mitrovica and Peltier (1991). The water load term for the first iteration is calculated on the assumption that the meltwater load is equal to the spatially uniform ESL. The water load for a second iteration is the spatially non-uniform sea-level change calculated by the first iteration. In this instance, our calculations had converged sufficiently by the second iteration and further iterations were not required.
In a standard spectral formulation, the sealevel solution is dependent on the maximum degree $\left(\mathrm{N}_{\max }\right)$ of truncation of the solution of the sea-level equation (Nakada and Lambeck, 1987; Mitrovica and Peltier, 1991; Johnston, 1993). The wavelength $\left(\lambda_{n}\right)$ corresponding to degree $n$ is defined by $2 \pi R / n$, where $R$ is the Earth's radius. Thus, the wavelength for the deformation of degree $\mathrm{N}_{\max }$ is the minimum wavelength required in the sea-level calculation. For the sea-level change produced by the deformation associated with the changes in ice load volume, it is possible to get a sufficiently converged solution by summing up the deformation to $\mathrm{N}_{\max }=50$ regardless of the viscosity model used. This ice-loading term is also constant for sites in the far-field, and does not contribute to the spatial variation of sea-levels observed for this area. The deformation due to meltwater loading is, however, significantly dependent on the viscosity model (Nakada and Lambeck, 1987). Sea-level variations for a spatially non-uniform water load at $6{ }^{14} \mathrm{C}$ kyr BP are depicted in Figure 4 as a function of $\mathrm{N}_{\max }$ for the sea-level solution, where three earth models are adopted. The upper $\left(\eta_{\mathrm{um}}\right)$ and lower mantle viscosities $\left(\eta_{1 \mathrm{~m}}\right)$ for all models are $2 \times$ $10^{20} \mathrm{~Pa} \mathrm{~s}$ and $10^{22} \mathrm{~Pa}$ s, respectively. This basic model has been derived from the sea-level varia-
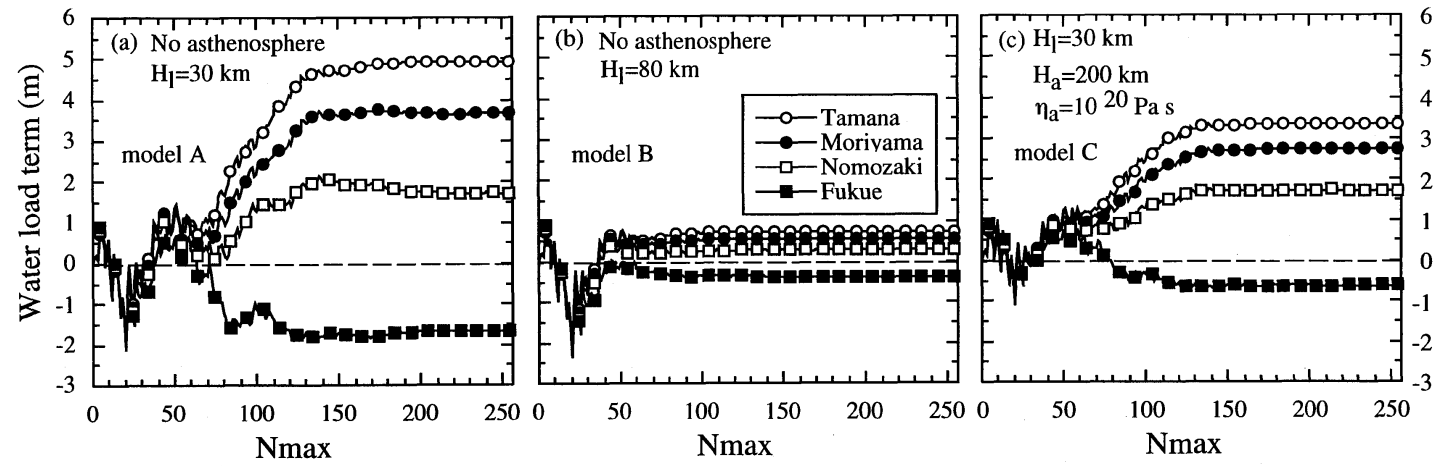

Fig. 4 Sea-level variations for a spatially non-uniform water loading at $6{ }^{14} \mathrm{C} \mathrm{kyr} \mathrm{BP}$ as a function of the degree $\left(\mathrm{N}_{\max }\right)$ of the solution of the sea-level equation

The upper and lower mantle viscosities for these models are $2 \times 10^{20} \mathrm{~Pa}$ s and $10^{22} \mathrm{~Pa} \mathrm{~s}$, respectively. Models $\mathrm{A}$ and $\mathrm{B}$ have no low-viscosity asthenosphere beneath the lithosphere, and $\mathrm{H}_{1}=30 \mathrm{~km}$ for $\mathrm{A}$ and $\mathrm{H}_{1}=80 \mathrm{~km}$ for $\mathrm{B}$. A low-viscosity asthenosphere exists for the model $\mathrm{C}$, and $\mathrm{H}_{1}=30 \mathrm{~km}, \mathrm{H}_{\mathrm{a}}=200$ $\mathrm{km}$ and $\eta_{\mathrm{a}}=10^{20} \mathrm{~Pa} \mathrm{~s}$. 
tions at sites in the Australian region (Nakada and Lambeck, 1989). Models A and B have no low-viscosity asthenosphere beneath the lithosphere, and the lithospheric thicknesses for these models are 30 and $80 \mathrm{~km}$, respectively. A low-viscosity layer with viscosity of $10^{20} \mathrm{~Pa} \mathrm{~s}$ and thickness of $200 \mathrm{~km}$ exists for the model C, and its lithospheric thickness is $30 \mathrm{~km}$.

For these models, sea-level components of degree less than 70 make a negligible contribution to spatial variation of sea-level in the farfield. For earth models with a thin lithosphere $(\sim 30 \mathrm{~km})$ significant spatial variation is attributed to sea-level components of degree $70<\mathrm{n}<150$, corresponding to wavelengths of $250-550 \mathrm{~km}$. Crustal deformations of wave lengths of about $400 \mathrm{~km}$ are elastically supported by a thick lithosphere $(\sim 80 \mathrm{~km})$, so that these components produce no significant spatial variation in sea-level. The spatial variation is also reduced for a rheological model with a low-viscosity asthenosphere (see model results for $\mathrm{A}$ and $\mathrm{C}$ ), and for the model $\mathrm{C}$ between Fukue and Tamana is about $3 \sim 4 \mathrm{~m}$. The spatial variation for this region is insensitive to the viscosity structure below $250 \mathrm{~km}$ depth, indicating that the crustal tilting observed here provides important constraints on the lithospheric thickness and asthenospheric viscosity and thickness.

\section{Results}

Figure 5-a shows the differential sea-level variations at $6{ }^{14} \mathrm{C}$ kyr BP between Fukue and Tamana as a function of lithospheric thickness $\left(\mathrm{H}_{1}\right)$ and asthenospheric viscosity $\left(\eta_{\mathrm{a}}\right)$. The asthenospheric thickness $\left(\mathrm{H}_{\mathrm{a}}\right)$ is assumed to be $200 \mathrm{~km}$, and the underlying upper mantle viscos ity is $2 \times 10^{20} \mathrm{~Pa}$ s. The differential sea-levels for these sites define a relatively restricted range of values in $\mathrm{H}_{1}{ }^{-} \eta_{\mathrm{a}}$ space that are consistent with the observations: of $30<\mathrm{H}_{1}<50 \mathrm{~km}$ and $8 \times$ $10^{19}<\eta_{\mathrm{a}}<2 \times 10^{20} \mathrm{~Pa}$ s. The asthenospheric viscosity increases with increasing lithospheric thickness. The viscosity contrast between the asthenosphere and its underlying layer is less than 10. An insignificant viscosity contrast has also been suggested by observations of sea-level variation in glaciated regions (Lambeck et al., 1996), and by the analyses of isostatic rebound of Lake Bonneville (Nakiboglu and Lambeck, 1983 ; Bills and May, 1987).

The sea-level predictions for western Kyushu are illustrated in Figure $5-b$, and are consistent with the observed crustal tilting. In these predictions, however, the minor Antarctic midto late-Holocene melting $(2 \sim 3 \mathrm{~m})$ is required,
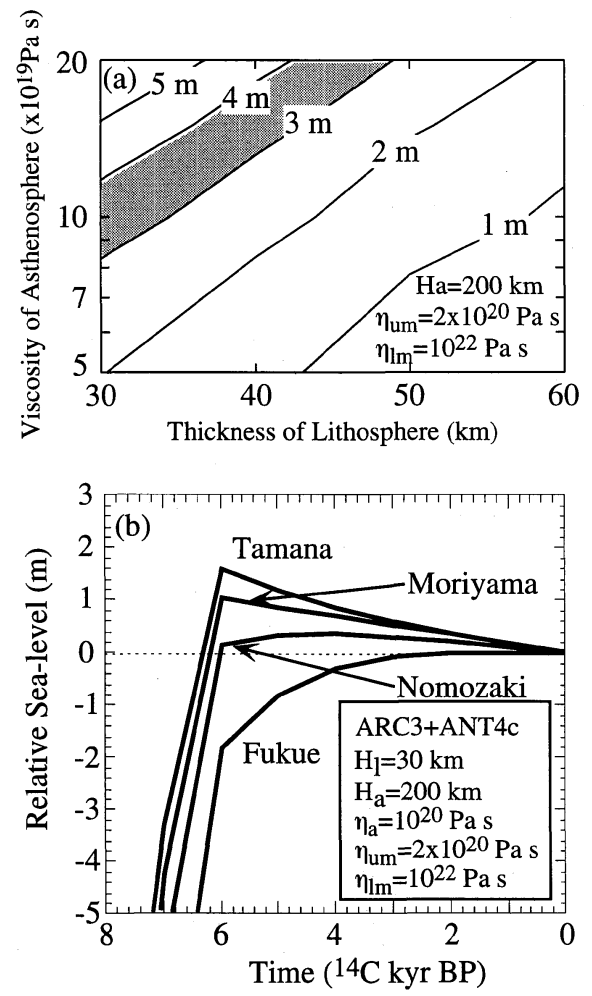

Fig. 5 Permissible rheological solutions and sea-level predictions

(a) Differential sea-level variations at $6{ }^{14} \mathrm{C} \mathrm{kyr}$ $\mathrm{BP}$ between Tamana and Fukue as a function of $\mathrm{H}_{1}$ and $\eta_{\mathrm{a}}\left(\mathrm{H}_{\mathrm{a}}=200 \mathrm{~km}\right)$.

The ice model used is ARC3+ANT4 (see the inset of Fig. 1). The shaded regions indicate the range of permissible rheological solutions.

(b) Predicted Holocene sea-levels for the ice model of ARC3+ANT4c (see the inset of Fig. 1).

Rheological parameters are shown in the figure. 
because the magnitudes of sea-levels at $6{ }^{14} \mathrm{C}$ kyr BP for all sites are systematically about $3 \mathrm{~m}$ higher than the observations. The magnitude of Antarctic melting estimated here is nearly the same as that inferred from the Australian (Nakada and Lambeck, 1988; Lambeck and Nakada, 1990) and European sea-level observations (Lambeck et al., 1996). This may indirectly support the rheological structure for the uppermost mantle estimated here and the tectonic stability of this region.

Predicted Holocene sea-levels (in metres) at $6{ }^{14} \mathrm{C}$ kyr BP are illustrated in Figure 1 for the model ARC3+ANT4c (see the inset of Fig. 1), $\mathrm{H}_{1}=30 \mathrm{~km}, \mathrm{H}_{\mathrm{a}}=200 \mathrm{~km}$ and $\eta_{\mathrm{a}}=10^{20} \mathrm{~Pa}$ s. The mid-Holocene underwater Jomon sites are systematically located in the region with sea-levels below the present level. Thus, mid-Holocene underwater Jomon sites observed in this region are reasonably explained by the hydro-isostatic adjustment including the solid-Earth deformation. In particular, this distribution is sensitive to the asthenospheric viscosity, which is a very important factor for studying mantle dynamics.

\section{Discussion and conclusion}

There is no doubt that the sea-level rise of about $100-120 \mathrm{~m}$ in the late glacial phase (20-6 kyr BP) had a significant impact on the development of human civilization in this period (Lambeck, 1996a, b) and landbridge problem (Nakada et al., 1991 ; Peltier, 1994 ; Elias et al., 1996) in particular. For example, Lambeck (1996a) discussed the effect of the late glacial sea-level variations on the civilization of Mesopotamia around the Persian Gulf. The postglacial sea-level variations, inevitably spatial- and time-dependent for a viscoelastic Earth, might have constrained the development of prehistoric human society.

The timing of the cultivation is an important indicator of the evolution of prehistoric human society (Kraft et al., 1977). Plants played a significant role as stable and efficient sources of nutrition, making large-scale settlement possible. Egyptian civilization, for example, was initiated by wide spread agriculture around the Nile delta (Stanley and Warne, 1993). It had been introduced as early as $8 \mathrm{kyr} \mathrm{BP}$ in the west of Nile valley (Wendorf et al., 1992). In Japan, while the Jomon period (ca. 12.0-2.3 kyr BP) was generally characterized as a nomadic hunter-gatherer society (e. g., Suzuki, 1990), the following era, the Yayoi period, is characterized by large well-established settlements dependent on rice as the staple crop of agricultural system that would dominate for the next 4 -5 kyr in Japan (e.g., Suzuki, 1990). The deceleration of sea-level rise deposited fine silty sediment and led to the development of fertile alluvial plains ideal for paddy fields. Subsequent hydro-isostatic uplift of the main island of Kyushu further extended these plains in the areas of Chikushi and Kumamoto plains (Fig. 1). The Yayoi site at Chikushi plain, for example, is an extremely large and well-developed settlement and is thought to have been the seat of one of the most influential dynasties in prehistoric Japan, the so-called Yamataikoku (e. g., Suzuki, 1990). However, alluvial plains were poorly developed in the western part of this study area, the Goto islands. This might have been due to subsidence by water-loading after eustatic sea-level rise in the late Pleistocene and early Holocene. Therefore, the fishing-based economy remained dominant even after the Jomon period, while rice agriculture was started in other areas of Kyushu (Amino et al., 1992).

Eustatic sea-level change had a significant effect on the development of prehistoric human culture (van Andel, 1989; Lambeck, 1996a,b), and the effect of subsequent crustal movement also significantly constrained the development of prehistoric human society (Kraft et al., 1977). Archaeological sites of this period will play a pivotal role in understanding the evolution of prehistoric Japanese culture. The bathymetric and topographic results of this study may provide a useful constraint on the possible locations of Jomon and Yayoi sites. 


\section{Acknowledgments}

We thank Dr A. P. Purcell for reading the manuscript carefully. We also thank Drs. E. Matsumoto, Y.Matsushima, H.Sato, I.Matsuda and Y.Sampei for their valuable comments. The constructive reviews by an anonymous reviewer significantly improved the manuscript.

\section{References}

Amino, T., Oobayashi, T., Tanigawa, K., Miyata, N. and Mori, K. (1992) East China sea and Saikai culture. 505p, Shougakukan (in Japanese)

Bard, E., Hamelin, B., Fairbanks, R.G. and Zindler, A. (1990) Calibration of the ${ }^{14} \mathrm{C}$ timescales over the past 30,000 years using mass spectrometric $\mathrm{U}-\mathrm{Th}$ ages from Barbados corals. Nature, 345 : 405-410

Bills, B.G. and May, G.M. (1987) Lake Bonneville: constraints on lithospheric thickness and upper mantle viscosity from isostatic warping of Bonneville, Provo, and Gilbert stage shorelines. J. Geophys. Res., 92 : 11493-11508

Chinzei Town Board of Education, Chinzei Town, Saga Prefecture (1989) Akamatu Underwater site. 89p, The Chinzei Town Board of Education, Saga Prefecture

Elias, A.A., Short, S.K., Nelson, C.H. and Birks, H.H. (1996) Life and times of the Bering land bridge. Nature, 382 : 60-63

Eisenhauer, A., Wasserburg, G. J., Chen, J.H., Bonani, G., Collins, L.B., Zhu, Z.R. and Wyrwoll, K. H. (1993) Holocene sea-level determination relative to the Australian continent: $\mathrm{U} / \mathrm{Th}$ (TIMS) and ${ }^{14} \mathrm{C}$ (AMS) dating of coral cores from the Abrolhos Island. Earth Planet. Sci. Lett., 114 : 529-547

Johnston, P.(1993) The effect of spatially nonuniform water loads on prediction of sea-level change. Geophys. J. Int., 114: 615-634

Kraft, J.C., Aschenbrenner, S.E. and Rapp, G. Jr. (1977) Paleogeographic reconstructions of coastal Aegean archaeological sites. Science, 195: 941-947

Lambeck, K. and Nakada, M. (1990) Late Pleis- tocene and Holocene sea-level change along the Australian coast. Palaeogeogr. Palaeoclimatol. Palaeoecol. (Global Planet. Change Section), 89: 143-176

Lambeck, K. (1996a) Shoreline reconstructions for Persian Gulf since the last glacial maximum. Earth Planet. Sci. Lett., 142 : 43-57

Lambeck, K. (1996b) Sea-level change and shoreline evolution in Aegean Greece since Upper Palaeolithic time. Antiquity, 70: 588-611

Lambeck, K., Johnston, P., Smither, C. and Nakada, M. (1996) Glacial rebound of the British isles-III. Constraint on mantle viscosity. Geophys. J. Int., 125 : 340-354

Mitrovica, J.X. and Peltier, W.R. (1991) On postglacial geoid subsidence over equatorial oceans. J. Geophys. Res., 96 : 20058-20071

Nagaoka, S. (1993) Takashima Underwater Jomon sites and sea-level changes. M. Miyamoto (ed.) Takashima Underwater Jomon Site II : 105-110, Nagasaki Prefectural Board of Education, Nagasaki Prefecture (in Japanese)

Nagasaki Prefectural Board of Education, Nagasaki Prefecture (1996) Research materials for the primitive and ancient history of Nagasaki Prefecture I. 836p, Nagasaki Prefectural Board of Education, Nagasaki Prefecture (in Japanese)

Nagasaki Prefectural Board of Education, Nagasaki Prefecture (1997) Research materials for the primitive and ancient history of Nagasaki Prefecture II. 802p, Nagasaki Prefectural Board of Education, Nagasaki Prefecture (in Japanese)

Nakada, M. and Lambeck, K. (1987) Glacial rebound and relative sea-level variations: a new appraisal. Geophys. J. R. astr. Soc., 90 : 171-224

Nakada, M. and Lambeck, K. (1988) The melting history of the late Pleistocene Antarctic ice sheet. Nature, 333 : 36-40

Nakada, M. and Lambeck, K. (1989) Late Pleistocene and Holocene sea-level change in the Australian region and mantle rheology. Geophys. J., $96: 497-517$

Nakada, M., Yonekura, N. and Lambeck, K. (1991) Late Pleistocene sea-level change in Japan: implications for tectonic histories and mantle rheology. Palaeogeogr. Palaeoclimatol. Palaeoecol., 
$85: 107-122$

Nakada, M., Maeda, Y., Nagaoka, S., Yokoyama, Y., Okuno, J., Matsumoto, E., Matsushima, Y., Sato, H., Matsuda, I. and Sampei, Y. (1994) Glacio-hydro-isostasy and underwater Jomon sites along the west coast of Kyushu, Japan. Quat. Res. (Daiyonki Kenkyu), 33:361-368 (in Japanese with English abstract)

Nakiboglu, S.M. and Lambeck, K. (1983) A reevaluation of the isostatic rebound of Lake Bonneville. J. Geophys. Res., 88 : 10439-10447

National Astronomical Observatory, Japan (1992) Rika nenpyou (Chronological Scientific Tables): 822-854, Maruzen

Ota, Y. and Omura, A. (1991) Late Quaternary shorelines in the Japanese Islands. Quat. Res. (Daiyonki Kenkyu), 30: 175-186

Peltier, W. R. (1994) Ice age paleotopography. Science, 265 : 195-201

Suzuki, K. (1990) The point issue of the Japanese history part 1. 304p, Shinjinbutsusha (in Japanese)

Stanley, D. J. and Warne, A. G. (1993) Sea level and initiation of Predynastic culture in the Nile delta. Nature, 363 : 435-438

The Research Group for Active Tectonics in Kyushu (1989) Active tectonics in Kyushu. 555p, Univ. Tokyo Press

van Andel, T. H. (1989) Late Quaternary sea-level changes and archaeology. Antiquity, 63: 733-746 Wendorf, F., Close, A.E., Schild, R., Wasylikowa, K., Housley, R.A., Harlan, J.R. and Krolik, H. (1992) Saharan exploitation of plants 8, 000 years BP. Nature, 359: 721-724

Yokoyama, Y., Nakada, M., Maeda, Y., Nagaoka, S., Okuno, J., Matsumoto, E., Sato, H. and Matsushima, Y. (1996) Holocene sea-level change and hydro-isostasy along the west coast of Kyushu, Japan. Palaeogeogr. Palaeoclimatol. Palaeoecol., 123: $29-47$ 


\title{
西九州の縄文の水中遺跡とハイドロアイソスタシー・ アセノスフェアの粘性率構造
}

\author{
中田正夫*1 - 奥野淳一*1 - 横山祐典*2 - 長岡信治 $* 3 \cdot$ \\ 高野晋司 $* 4 \cdot$ 前田保夫*5
}

（要 旨）

西九州には, 縄文前期から縄文中期の水中遺跡が存在 する. 最終水期の大陸水床の融解に伴うハイドロアイソ スタティックな地壳傾動は，これらの遺跡の沈水を定量 的に説明することができる.これらの水中遺跡の分布は, 地球の約 $250 \mathrm{~km}$ までの梁さの粘性構造に敏感に対応し た事実を示している.この地域の海面変化の観測值と理 論值を比較検討した結果, 観測值を説明しうる粘性構造 は, リソスフェアの厚さが $30 \sim 50 \mathrm{~km}$, リソスフェア下 $200 \mathrm{~km}$ のアセノスフェアの平均的な粘性率が（8〜
20) $\times 10^{19} \mathrm{~Pa}$ s であることが判明した.つまり，アセノ スフェアとその下の上部マントルとの粘性率のコントラ ス卜は有意ではなく，日本列島のような島弧域において も，発達した低い粘性率のアセノスフェアは存在しない ことが示唆される.さらに，ハイドロアイソスタティッ クな地款傾動に規定された後水期の海水準変動は, 空 間・時間的に变化し, 先史時代の居住地や生活様式を規 定した可能性がある.

*1 九州大学理学部地球惑星科学教室 † 812-8581 福岡市東区箱崎 6-10-1.

*2 オーストラリア国立大学地球科学研究所 キャンベラ, A.C.T. 0200, オーストラリア.

*3 長崎大学教育学部地理学教室 $=852-8131$ 長崎市文教町 1-14.

*4 長崎県教育庁文化課 干 850-8570 長崎市江戸町 2-13.

*5 フィリピン大学 地質科学研究所 ケソン市, 1101, フィリピン. 